\title{
Логунова Е.B. \\ Роль сферы дополнительного образования в процессе формирования российской национальной идентичности
}

Тюменский государственный университет (Россия, Тюмень»)

doi 10.18411/spc-04-12-2017-10

idsp 000001:spc-04-12-2017-10

\section{Аннотация}

Феномен российской национальной идентичности, формы и способы ее актуализации в деятельности человека сейчас еще только изучаются научным сообществом. Педагогическое сообщество, опираясь на свой профессиональный опыт и собственное видение социальных перспектив нашей страны, уже активно осуществляет процесс формирования российской национальной идентичности как цельного комплекса идентификационных характеристик человека - гражданина Российской Федерации. Образовательная среда дополнительного образования обладает рядом преимуществ в организации данного процесса в силу вариативности, гибкости и многообразия видов и форм практической деятельности ребенка и подростка, в ходе которой происходит спонтанный творческий процесс самоактуализации и самоосознания личности. Педагоги дополнительного образования также выполняют компенсаторную функцию в сфере детско-родительских отношений, способствуя формированию полноценной позитивной идентичности личности воспитанников.

Ключевые слова: российская национальная идентичность, образовательная среда, дополнительное образование, формирование идентичности личности.

\section{Abstract}

A phenomena of Russian national identity, ways and forms of its actualization in personal activity are in investigational process of scientific community. Whereas pedagogical community in Russia, relying to its professional experience and its own vision of social perspectives of the countryis actively implementing the process of Russian national identity formation as integral complex of identification specifications of the person - the citizen of Russian Federation. The educational environment of additional educationin Russia possesses a diverse numberof advantages in the implementing of Russian national identity formation due to variability and flexibility of practical activitieswhich provides spontaneous creative process of self-actualisation and person'sself-awareness.Likewisethe additional education teachers have a compensatory function in the sphere of child-adult relations, promoting normal positive personal identity for mationas well.

Keywords: Russian national identity, educational environment, additional education, personal identity formation.

Речь о необходимости формирования российской национальной идентичности как о воплощении национальной идеи России, могущей объединить все народы, проживающие на территории Российской федерации, зашла сравнительно недавно. В последней редакции ФГОС для сферы общего образования говорится о необходимости формирования у детей и подростков целого ряда идентичностей, в частности личностной, групповой (этнокультурной), российской гражданской идентичностей [2]. На прошедшем в Астрахани 31.10 .16 заседании Совета по межнациональным отношениям, посвящённом актуальным вопросам реализации Стратегии государственной национальной политики России уже шла речь о процессе формирования российской общенациональной идентичности как комплексе мировоззренческих установок, присущих гражданину РФ [1]. 
До сих пор академическое сообщество не выработало четкого однозначного определения, что такое российская национальная идентичность, но можно выделить одно мнение: все существующие виды идентичности - личностная, гендерная, семейная, сетевая, религиозная, политическая, социальная, этническая, общегражданская, профессиональная входят в качестве неотъемлемых составляющих в российскую национальную идентичность.Также бесспорным является тот факт, что идентичность формируется не исключительно сама по себе, а в процессе самореализации личности в окружении и под воздействием социума, в процессе ее воспитания и саморазвития, в процессе ее ежедневнойтрудовой, познавательной, творческой, спортивной и рекреативной деятельности.

По современному реальному состоянию воспитательного процессасистема общего образования «делегировала» функцию комплексного воспитания детей, подростков и молодежи во внеучебное время системе дополнительного образования, разного рода общественным молодежным организациям, которые также курируются Департаментом по спорту и молодежной политике.Таким образом, можно сказать, что на современном этапе система дополнительного образования несет серьезную ответственность за то, каким будет комплекс идентификационных характеристик гражданина РФ в самом недалеком будущем и в предстоящие несколько десятилетий.

Сфера дополнительного образования выступает как универсальная образовательная среда, позволяющая добиться максимального эффекта в процессе формирования российской национальной идентичности. Объективно, работники сферы дополнительного образования - педагоги, тренера, административные работники, даже технический персонал выполняют эту функцию в силу ряда особенностей социальноэкономического состояния России уже с середины 90-х годов 20 века. Академическое научное сообщество еще не выявило прозрачных механизмов формирования российской национальной идентичности и обращает внимание на констатацию фактов о наличии знаний, представлений, эмоциональных отношений [3,136].В то же время педагоги, опираясь на свои представления об идеальной личности гражданина России, на личные профессиональные знания и навыки, на собственную интуицию, уже осуществляют практический процесс формирования данной идентичности в ходе воспитания ребенка, его погружения в событийно-образовательную среду, где воспитанник не только получает знания, а в первую очередь действует, самореализуется.

Ребенок, подросток активно и творчески действует в образовательном пространстве подросткового клуба, спортивной секции, кружка по интересам, проживает свои эмоциональные переживания, получает необходимую для его развития ответную реакцию социума по целому комплексу жизненных ситуаций, которые, кстати, в сфере общего образования не могут произойти просто по определению.

Также нельзя забыть о том, что на рубеже эпох очень сильно пострадала сфера детско-родительских отношений, когда дети фактически выпадали из поля зрения работающих родителей на многие годы. Многие подростки полноценно сформировались нравственно и физически только благодаря упорному труду педагогов, интуитивно понимавших, что кроме них воспитывать подрастающие поколения в 90-х было просто некому. Очевидно, что зачастую педагог дополнительного образования выполнял компенсаторную роль в жизни ребенка - ко многим тренерам, например, мальчишки обращались за советом как к наставникам в связи с отсутствием собственных отцов, множество детей практически вырастало в стенах клубов или спортивных учреждений.

На сегодняшнем этапе проблема детско-родительских отношений не становится менее острой - педагоги сталкиваются с целым поколением молодых родителей, которые не знают, как воспитывать детей и готовы переложить эту функцию на плечи профессионалов. Данная категория родителей видит в сфере образования агента 
дисциплинирующего влияния, выдвигающего требования, рисующего перспективу развития ребенка, а молодые родители либо подчиняются видению и рекомендациям педагога, либо их избегают, устраняясь от выполнения назидательной воспитывающей роли в семье, относясь к своему ребенку как «к другу». Подобная социальная незрелость родителей возлагает еще большую ответственность на сферу образования в плане формирования морально-нравственных ценностей и российской национальной идентичности подрастающих поколений.

Если говорить подробнее об определении российской национальной идентичности, то можно сказать, что в нее входит весь комплекс идентичностей личности, сформировавшейся в поле влияния так называемой «русской цивилизации» с еe культурными кодами, приверженностью к традиции, интернационализмом, ориентирами на социальную справедливость, на внутреннее саморазвитие. Практически вся деятельность педагога направлена на формирование целого ряда идентичностей в каждом воспитаннике, но у конкретного педагога в соответствии со спецификой его направления могут реализовываться подходы к определенному комплексу идентификационных характеристик.

Так, например, педагоги спортивно-оздоровительных направлений актуализируют подходы к формированию гражданской идентичности через проживание чувства патриотизма, гордости за свою команду, за свою страну в ходе спортивных соревнований, но большее внимание они уделяют формированию личностной и профессиональной идентичности. Педагоги, работающие по программам патриотической направленности, формируют личностную и групповую, коллективистскую идентичность, политическую, общегражданскую, но меньше внимания уделяют профессиональной, сетевой, семейной идентичностям. И надо отметить, что, к сожалению, этнокультурному компоненту и формированию позитивной этнической идентичности в рамках идеи общенационального единства у детей, подростков и молодежи в городе Тюмени уделяется мало внимания как в программах, так и в общем плане мероприятий, особенно если сравнивать в долевом отношении с тем, насколько широко развернута данная работанапример, в Свердловской, Челябинской областях, в регионах ЯНАО и ХМАО по формированию этнокультурных компетенций и умения вести повседневный диалог культурразных этносов.

Для уяснения теоретических основпо формированию идентичности, необходимо помнить, что любая идентичность как конструкт сферы самосознания личности, состоит из трех компонентов $[4,10]$. То есть любая идентичность предполагает наличие определенных знаний, связанных с ней эмоциональных переживаний, отношений. Деятельность педагога всегда направлена на то чтобы создать положительный эмоциональный фон, позитивную мотивацию для ребенка. И третий аспект, без которого, собственно, говорить о сформированности какой-либо идентичности не приходится, это деятельностный компонент. Человек в конечном итоге должен не только знать и чувствовать себя сыном, отцом, инженером или спортсменом, русским, азербайджанцем, татарином или вообще гражданином РФ, но и уметь проявлять себя и свою уникальность в жизни, в каждодневных действиях.

И сфера дополнительного образования обладает уникальными возможностями создания универсальной образовательной среды, в которой личность не только получает знания и эмоциональные переживания, но и проявляется в действии. Сфера дополнительного образования создает условия для комфортной апробации ребенком и подростком своего деятельностного потенциала в самых разных социальных ролях благодаря наличию на одной площадке, в рамках одной образовательной среды нескольких направлений деятельности. Она предполагает большую степень свободы, творческого раскрепощения личности воспитанника, его включенность в самые разнообразные сферы самостоятельной деятельности. Почему педагоги 
дополнительного образования порой и говорят,что они знают ребенка лучше, со всеми его достоинствами и недостатками, нежели школа и даже семья.

В этом бесспорное преимущество сферы дополнительного образования: оно не только дает знания, не только формирует морально-нравственные качества, общую самооценку личности, но и имеет социально-безопасные площадки для спонтанной и заданной деятельностнойсамоактуализации любого воспитанника, начиная от инклюзивного, девиантноготипа и до разносторонне одаренного. Что и является необходимым условием для полноценного формирования личностной, групповой, сетевой, семейной, этнической, профессиональной, гражданско-патриотической идентичностей и в конечном итоге российской национальной идентичности как совокупности всех видов идентичностей личности гражданина РФ.

Несмотря на то, что в общем и целом феномен российской национальной идентичности, формы и способы ее актуализации в деятельности человека сейчас еще только изучаются научным сообществом, педагогическое сообщество зачастую интуитивно, опираясь на свой профессиональный опыт и собственное видение социальных перспектив нашей страны, уже активно осуществляет процесс формирования российской национальной идентичности как цельного комплекса идентификационных характеристик человека - гражданина Российской Федерации, продолжателя истории и традиций российской государственности, носителя идей и нравственных убеждений уникальной русской цивилизации, в которой веками реализовывалась идея о мирном и продуктивном сосуществовании самых разных народов, рас и вероисповеданий в рамках одного государства.

$$
* * *
$$

1. Заседание Совета по межнациональным отношениям, 31 октября 2016 года "\ Текст [Электронный pecypc] http://www.kremlin.ru/events/president/news/53173 (дата обращения: 06.10.2017).

2. Федеральный государственный образовательный стандарт основного общего образования (утв. приказом Министерства образования и науки РФ от 17 декабря 2010 г. N 1897)\Текст [Электронный pecypc] Система ГАРАНТ: http://base.garant.ru/55170507/\#ixzz4vpCuYyFY (дата обращения: 06.10.2017).

3. Дробижева Л.М. Российская идентичность в массовом сознании. \І Журнал «Вестник российской нации» - Москва: Изд-во «Общероссийский союз общественных объединений содействия укреплению государственного единства "Российская нация", 2009, стр.136

4. Э. Эриксон. Идентичность: юность и кризис. Перевод с английского. Общая редакция и предисловие.доктора психологических наук. А. В. Толстых. - Москва: Издательская группа "Прогресс", 1996, стр.10

\title{
Муранец А.П., Боровиков С.Н. \\ Проблемы преподавания в ВУЗе биологических дисциплин в век «информатизационного взрыва»
}

\author{
КАТУ им. С.Сейфуллина
} (Казахстан, Астана»)

doi 10.18411/spc-04-12-2017-11

idsp 000001:spc-04-12-2017-11

\section{Аннотация}

Для повышения качества подготовки специалистов биологического направления требуется создание качественно новой концепции логистики знаний, адаптированной под современные скорости накопления, обновления и доступа к информации. Главная задача преподавателя биологии - это задать вектор, в котором необходимо определить основные понятия и положения биологии.

Ключевые слова: информация, биология, интернет, студент 